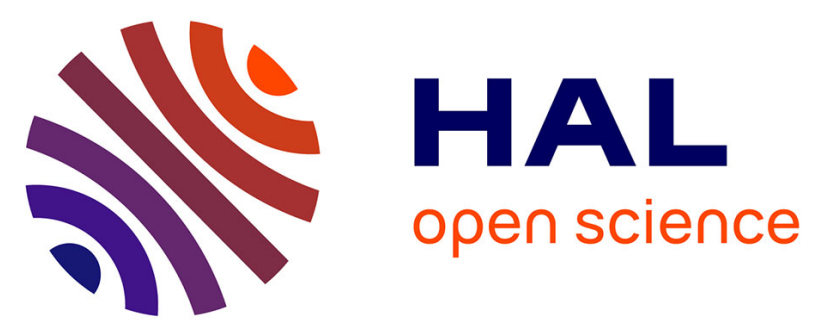

\title{
Fine-scale velocity structure of upper oceanic crust from full waveform inversion of downward continued seismic reflection data at the Lucky Strike Volcano, Mid-Atlantic Ridge
}

\author{
A. F. Arnulf, A. J. Harding, S. C. Singh, G. M. Kent, W. Crawford
}

\section{To cite this version:}

A. F. Arnulf, A. J. Harding, S. C. Singh, G. M. Kent, W. Crawford. Fine-scale velocity structure of upper oceanic crust from full waveform inversion of downward continued seismic reflection data at the Lucky Strike Volcano, Mid-Atlantic Ridge. Geophysical Research Letters, 2012, 39, pp.747-759. 10.1029/2012GL051064 . insu-03583354

\section{HAL Id: insu-03583354 \\ https://hal-insu.archives-ouvertes.fr/insu-03583354}

Submitted on 22 Feb 2022

HAL is a multi-disciplinary open access archive for the deposit and dissemination of scientific research documents, whether they are published or not. The documents may come from teaching and research institutions in France or abroad, or from public or private research centers.
L'archive ouverte pluridisciplinaire HAL, est destinée au dépôt et à la diffusion de documents scientifiques de niveau recherche, publiés ou non, émanant des établissements d'enseignement et de recherche français ou étrangers, des laboratoires publics ou privés.

$$
\text { Copyright }
$$




\title{
Fine-scale velocity structure of upper oceanic crust from full waveform inversion of downward continued seismic reflection data at the Lucky Strike Volcano, Mid-Atlantic Ridge
}

\author{
A. F. Arnulf, ${ }^{1,2}$ A. J. Harding, ${ }^{3}$ S. C. Singh, ${ }^{1}$ G. M. Kent, ${ }^{4}$ and W. Crawford ${ }^{1}$ \\ Received 15 February 2012; revised 20 March 2012; accepted 22 March 2012; published 21 April 2012.
}

[1] We present a fine-scale 2D velocity structure beneath the Lucky Strike Volcano on the Mid-Atlantic Ridge (MAR) using an elastic full waveform inversion (FWI) method. The FWI is a data driven procedure that allows simultaneous exploitation of both reflections and refractions energy in multi-channel seismic data to create a single self-consistent, high-resolution velocity image of the upper crust that can be used for geologic interpretation. The long-wavelength background P-wave velocity model required by the local optimization approach was created using a combination of downward continuation and 3D first-arrival travel-time tomography. The elastic waveform inversion was applied to carefully windowed downward continued data, where wideangle reflections and refractions arrive in front of the waterwave and are thus isolated from the high-amplitude seafloor scattering energy that is particularly acute in areas of rough igneous seafloor. Waveform inversion reduces the misfit of the initial model by $76 \%$ after 19 iterations and strongly reduced the size of the residuals relative to the signal size. The final model shows fine scale structure beneath the northern part of the Lucky Strike volcano on a resolution of tens of meters. Evidence for successive lava sequences testifies to the constructional origin of the upper section of layer 2A. Normal faults are revealed within the shallow crust and are strongly correlated with seafloor observations. Citation: Arnulf, A. F., A. J. Harding, S. C. Singh, G. M. Kent, and W. Crawford (2012), Fine-scale velocity structure of upper oceanic crust from full waveform inversion of downward continued seismic reflection data at the Lucky Strike Volcano, MidAtlantic Ridge, Geophys. Res. Lett., 39, L08303, doi:10.1029/ 2012GL051064.

\section{Introduction}

[2] Numerous seismic investigations have been conducted to study the structure of the upper crust at slow [e.g., Hussenoeder et al., 2002; Seher et al., 2010a; Arnulf et al., 2011], intermediate [Canales et al., 2005] and fast spreading ridges [Harding et al., 1989, 1993; Kent et al., 1993], but

\footnotetext{
${ }^{1}$ Laboratoire de Géosciences Marines, Institut de Physique du Globe de Paris, Paris, France.

${ }^{2}$ Now at Cecil H. and Ida M. Green Institute of Geophysics and Planetary Physics, Scripps Institution of Oceanography, University of California, San Diego, La Jolla, California, USA.

${ }^{3}$ Cecil H. and Ida M. Green Institute of Geophysics and Planetary Physics, Scripps Institution of Oceanography, University of California, San Diego, La Jolla, California, USA.

${ }^{4}$ Nevada Seismological Laboratory, University of Nevada, Reno, Reno, Nevada, USA.

Copyright 2012 by the American Geophysical Union. 0094-8276/12/2012GL051064
}

so far the only boundary that is usually imaged with multichannel seismic (MCS) reflection methods corresponds to the high velocity gradient zone at the base of layer $2 \mathrm{~A}$. Although the quasi two-dimensional nature of the oceanic crust at fast spreading centers has lead several authors [Christeson et al., 1996; Harding et al., 1993; Kent et al., 1993] to associate the layer $2 \mathrm{~A} / 2 \mathrm{~B}$ transition zone with a lithological boundary between lava flows and sheeted dikes, the heterogeneous and intrinsically $3 \mathrm{D}$ nature of the oceanic crust at slow spreading ridges or in the vicinity of features like transform faults make it difficult to accept that such an association is universal [Christeson et al., 2007]. Traditional travel time tomography methods over-smooth the vertical and horizontal velocity structure of the upper crust while MCS processing has concentrated on the wide-angle reflection imaging of the base of layer $2 \mathrm{~A}$ with little emphasis on the velocity, even interval velocity estimates for layer $2 \mathrm{~A}$ can be problematic because of non-hyperbolic moveout [Harding et al., 1993].

[3] The conventional reflection and refraction methods provide complementary but incomplete images of the oceanic crust. FWI is an attractive method because it allows simultaneous exploitation of both wide-angle reflections and refractions in MCS data to create a single self-consistent, high-resolution velocity image of the upper crust that can be used for geologic interpretation. The FWI technique is a very powerful method that iteratively attempts to match synthetically calculated data with observed data. This approach is a data-driven form of analysis that leads to high-resolution imaging by extracting quantitative information from the seismograms. Recent advances in high-performance computing and MCS wide-aperture acquisition has made 2D FWI feasible on multi-processor desktop computers. One aspect of the mid-ocean ridge data that is a problem for 2D FWI is the strength of seafloor scattering, which obscures later arrivals, is intrinsically 3D and hard to predict deterministically. One way of avoiding this problem is to invert only energy that arrives ahead of the seafloor reflection on surface data [Canales, 2010], but this strategy would miss the shallowest part of the crust in deep waters. Here, we combine downward continuation [Arnulf et al., 2011] with FWI to determine the fine-scale P-wave velocity structure across the Lucky Strike volcano from the seafloor down to $\sim 1 \mathrm{~km}$ depth. The downward continuation brings more of the shallowest refraction energy ahead of the seafloor reflection and simultaneously acts as a $2 \mathrm{D}$ filter to improve the signal-to-noise ratio.

\section{The SISMOMAR Experiment}

[4] The Lucky Strike volcano is located at $\sim 37^{\circ} 18^{\prime} \mathrm{N}$ along the Mid-Atlantic Ridge (MAR) and lies in the middle of the 


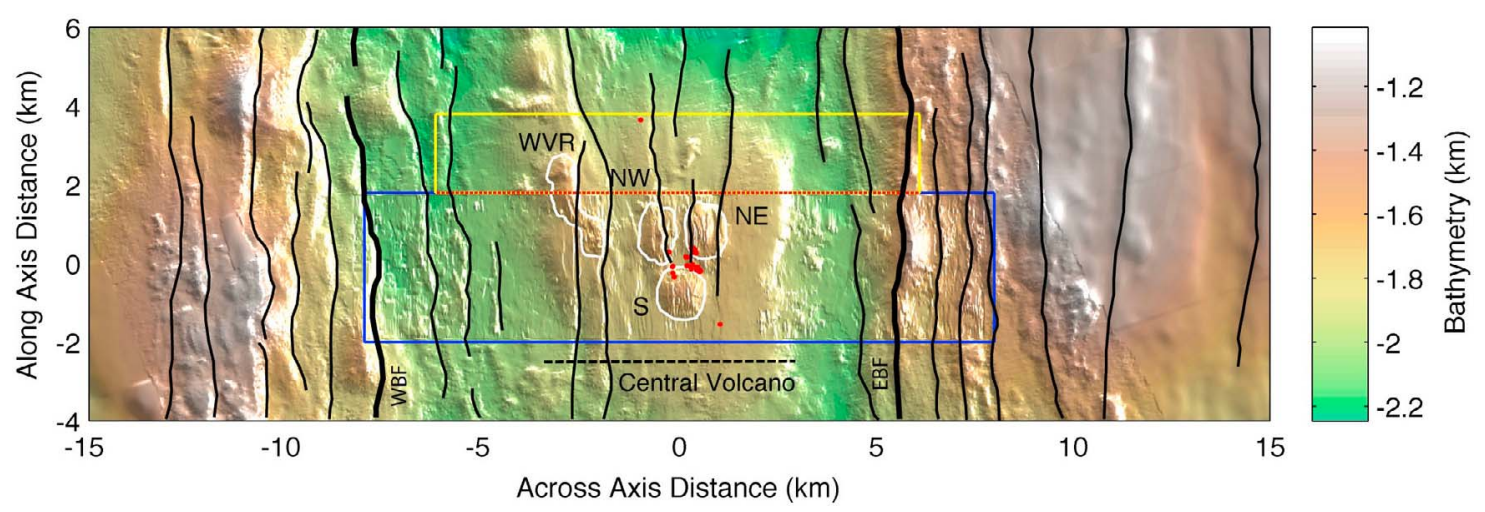

Figure 1. Bathymetric map of the central part of the Lucky Strike segment. Black lines highlight faults, white lines show the extent of the different summital constructional features and red dots over the volcano mark the hydrothermal vents. The blue box shows the extent of the 3D SISMOMAR MCS experiment. The extent of the section from line 39 in Figure 3 is shown by the dashed red line. The yellow rectangle marks the extent of Figure 4. S: southern, NW: north western and NE: north eastern summital volcanic edifices; WVR: western volcanic ridge.

70-km long Lucky Strike segment, $\sim 400 \mathrm{~km}$ to the southwest of the probable Azores hotspot location [Moreira et al., 1999]. This is a typical slow-spreading ridge segment with a $15-20 \mathrm{~km}$ wide axial valley that hosts a $0.3-0.4 \mathrm{~km}$ axial high. The Lucky Strike volcano $\sim 7 \mathrm{~km}$ in diameter is bounded by two major normal faults with $0.5-0.9 \mathrm{~km}$ escarpments, the eastern and western bounding faults (EBF, WBF, Figure 1) [Detrick et al., 1995]. Beyond the rift valley walls the seafloor morphology is dominated by faultcontrolled abyssal hills [Detrick et al., 1995] and DSL-120 side scan data indicate that the central volcano is highly tectonized [Humphris et al., 2002]. Recent magmatism has been reported at several locations within the Lucky Strike volcano, including the central lava lake location, the three surrounding summital volcanic cones [Ondréas et al., 1997, 2009; Humphris et al., 2002], and at a volcanic edifice located northwest of the central volcano, the western volcanic ridge [Fouquet et al., 1994] (Figure 1).

[5] The multichannel reflection data are from the 2005 SISMOMAR experiment [Singh et al., 2006] acquired onboard the French R/V L'Atalante to study the central part of the Lucky Strike segment. The data were collected as $11 \mathrm{~s}$ long records sampled at $2 \mathrm{~ms}$ and contain usable frequencies between $\sim 6-45 \mathrm{~Hz}$ with a dominant frequency of $15 \mathrm{~Hz}$. Previous analyses of the 3D MCS data have imaged opposing axial bounding faults down to $3-4 \mathrm{~km}$ depth, and a $7 \mathrm{~km}$ long and 3-4 km wide axial magma chamber (AMC) [Singh et al., 2006; Combier, 2007; V. Combier et al., Three-dimensional geometry of magma chamber and faults at the Lucky Strike Volcano, Mid-Atlantic Ridge, submitted to Journal of Geophysical Research, 2011] in the intervening region some $3.2 \mathrm{~km}$ below the seafloor. Furthermore, two OBSbased tomography experiments were carried out during the SISMOMAR cruise that revealed two low velocity zones (LVZ) within this median valley: a lower crustal LVZ below the axial melt lens that was interpreted as a region of partial melt [Seher et al., 2010b] and a shallow crustal LVZ that was linked to high-porosity volcanic formations [Seher et al., 2010c]. However, due to the low resolution of the OBS tomographic method, only large-scale velocity differences were determined. In order to increase the resolution, Arnulf et al. [2011] have utilized a downward continuation method, which they call Synthetic Ocean Bottom Experiment
(SOBE), to propagate the seismic streamer data backwards in time and down to a datum close to the seafloor. This process collapses the seafloor reflections while simultaneously unfolding the triplication from the base of the layer $2 \mathrm{~A}$ and transforming the layer $2 \mathrm{~A}$ refractions into first arrivals. The isolation of refractions from seafloor scattering facilitates both travel-time and waveform analysis. A tomographic inversion of these data combined with stacking of reflection data revealed new shallow reflectors (2Aa) at the top of the layer 2A gradient zone [Arnulf et al., 2011]. However, spatial resolution is still on the order of hundreds of meters, preventing the seismic images from determining the internal structure of the lava sequences. In this paper, we examine the fine-scale velocity structure (50-100 m scale) of the upper crust by utilizing FWI of downward continued MCS data to the seafloor.

\section{Waveform Inversion}

[6] Elastic FWI is a data-fitting method based on fullwavefield modelling of all waveforms present in the data that enables quantitative imaging of subsurface elastic parameters from multichannel seismic data. The inversion algorithm used here was originally developed by Tarantola [1986] and refined by Shipp and Singh [2002] for long offset marine data; Sears et al. [2010] extended this technique to ocean bottom cable data. The forward modeling of the full elastic wavefield and back propagation of the residual wavefield are calculated in the time domain using a fourth order in space, second order in time finite difference scheme [Levander, 1988], distinguishing this approach from frequency domain methods [Pratt, 1999; Operto et al., 2004; Sirgue and Pratt, 2004; Virieux and Operto, 2009]. A common element of both these methods is the iterative use of a local search direction to solve the non-linear problem. Convergence to the global minimum rather than a local minimum requires an accurate starting model that contains the long and possibly the intermediate wavelengths of the true velocity model.

[7] The 2D P-wave starting model (Vp) along our profile was extracted from the high-resolution 3D tomographic velocity model of the downward continued data [Arnulf et al., 2011]. The initial Vs velocity model was calculated from Vp assuming a Poisson ratio of 0.4 in the shallow crust and 0.3 at 


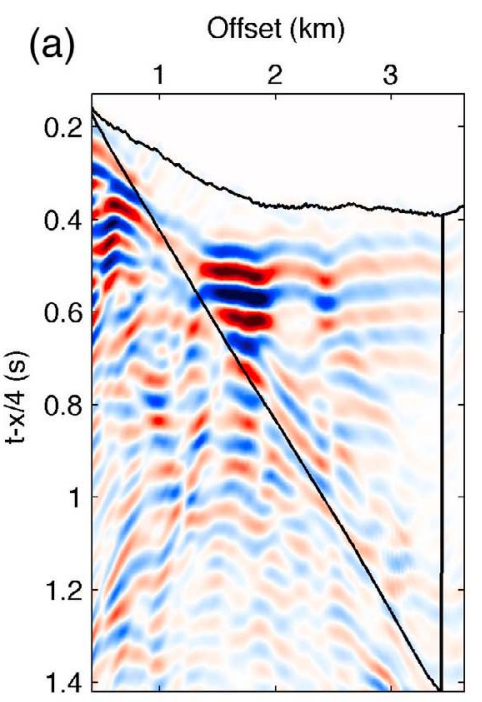

(d)

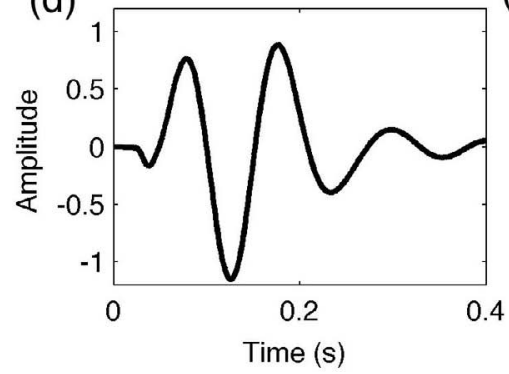

(b)

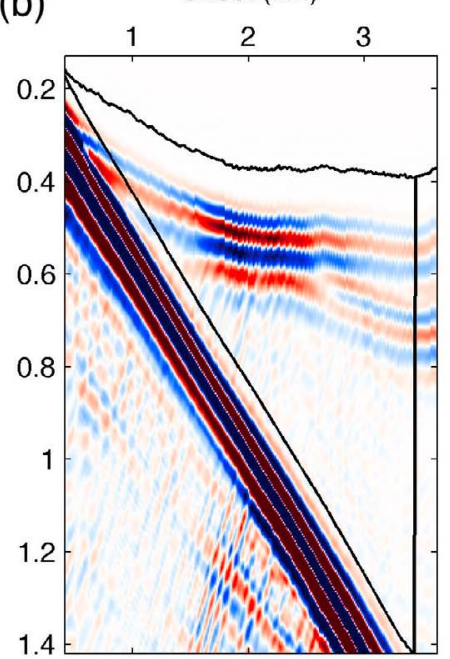

(e)

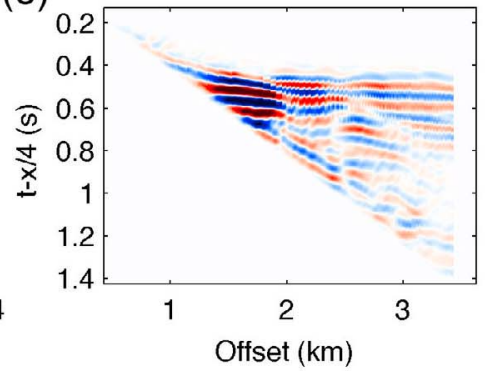

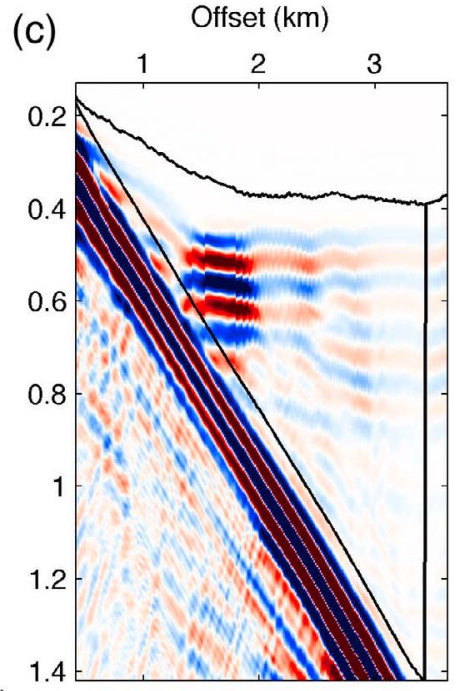

(f)

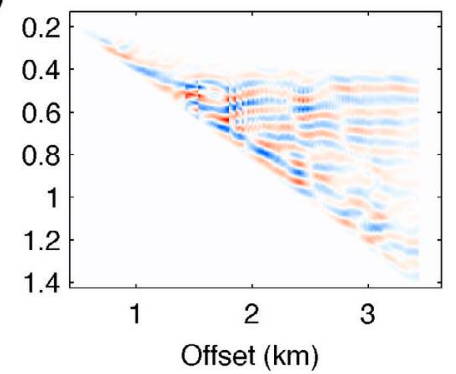

Figure 2. Data Misfit corresponding to our windowed waveform inversion. (a) Shot gather 38550 from the SISMOMAR data downward continued to a datum $75 \mathrm{~m}$ above the seafloor. This shot gather is located at $2.375 \mathrm{~km}$ across axis and the receivers are located east of the shot. Only refractions and reflections observed in front of the water wave were inverted. (b) Initial synthetic. (c) Final synthetic. (d) Final source wavelet. (e) Initial residuals ( $\sim 123 \%$ of the data size). (f) Final residuals $(\sim 17 \%$ of the data size). The initial correlation coefficient computed between the initial synthetics and the field data for this specific shot was 0.23 ; it was increased to 0.915 for the final residuals.

the base of layer 2A. We did not inverted for density, which was updated after each iteration using empirical relationships with P-wave velocities [Gardner et al., 1974; Hamilton, 1978]. No attenuation was included in the modelling. The initial waveform forward modelling showed that the background velocities can accurately predict first arrival travel times within $\sim 10 \mathrm{~ms}$, consistent with the tomographic inversion estimates. Besides the starting velocity model, inputs for the waveform inversion included preprocessed shot data and the recovery of a source wavelet. The required initial preprocessing of the field data was however straightforward and accomplished as part of the downward continuation stage. A 4th-order Butterworth band-pass filter with corner frequencies of 3 and $10 \mathrm{~Hz}$ was first applied to window the data in the frequency range that satisfies the stability criteria of the $12.5 \mathrm{~m}$ regular finite-difference grid [Levander, 1988]. Second, the data were pre-processed by multiplying the amplitudes of the real data by $\sqrt{t}$ (where $t$ is the two-way traveltime) and convolving with $1 / \sqrt{t}$ to correct the amplitudes and phases from 3D (point source) to 2D (line source) [Shipp and Singh, 2002]. Then the observed data were rescaled using a common scaling factor for the whole seismic line and resampled to $1 \mathrm{~ms}$ to match the sample interval of the finite-difference modeling. A Kirchhoff implementation of the downward continuation method was used to transform the surface data to a datum $75 \mathrm{~m}$ above the seafloor
[Berryhill, 1979, 1984; Shtivelman and Canning, 1988; Larkin and Levander, 1996]. Using the downward continued data for waveform inversion has several advantages. The wavefield can be sampled at the exact grid point locations defined by our finite-difference grid leading to a more accurate computation of the misfit function for each shot. It greatly increases the efficiency of the time domain modeling by deploying sources and receivers deeper in the water layer. It allows straightforward windowing of the data to include the refraction arrivals and wide-angle reflections of interest (Figure 2). The estimation of the original source wavelet was carried out following the method presented by Collier and Singh [1997]. An appropriate source wavelet was extracted from stacks of the nearest 3 traces of 20 shots over the smoother eastern flank of the volcano, 1.4-2.2 km distance (Figure 3), then band pass filtered to match the downward continued data (Figure 2d).

[8] The inversion strategy targeted the energy corresponding to the refraction events and wide-angle reflections. A total of 148 shots, spaced at $75 \mathrm{~m}$ were inverted. Inversion was stopped after 19 iterations, when the misfit was reduced to $\sim 76 \%$ of the initial value (Figure 2). The source wavelet was also updated during the inversion following the frequency domain procedure of Pratt [1999]. Figure 2 shows that waveform inversion has been able to fit a significant part of the data. The data residuals, which were originally $134.4 \%$ of the data 

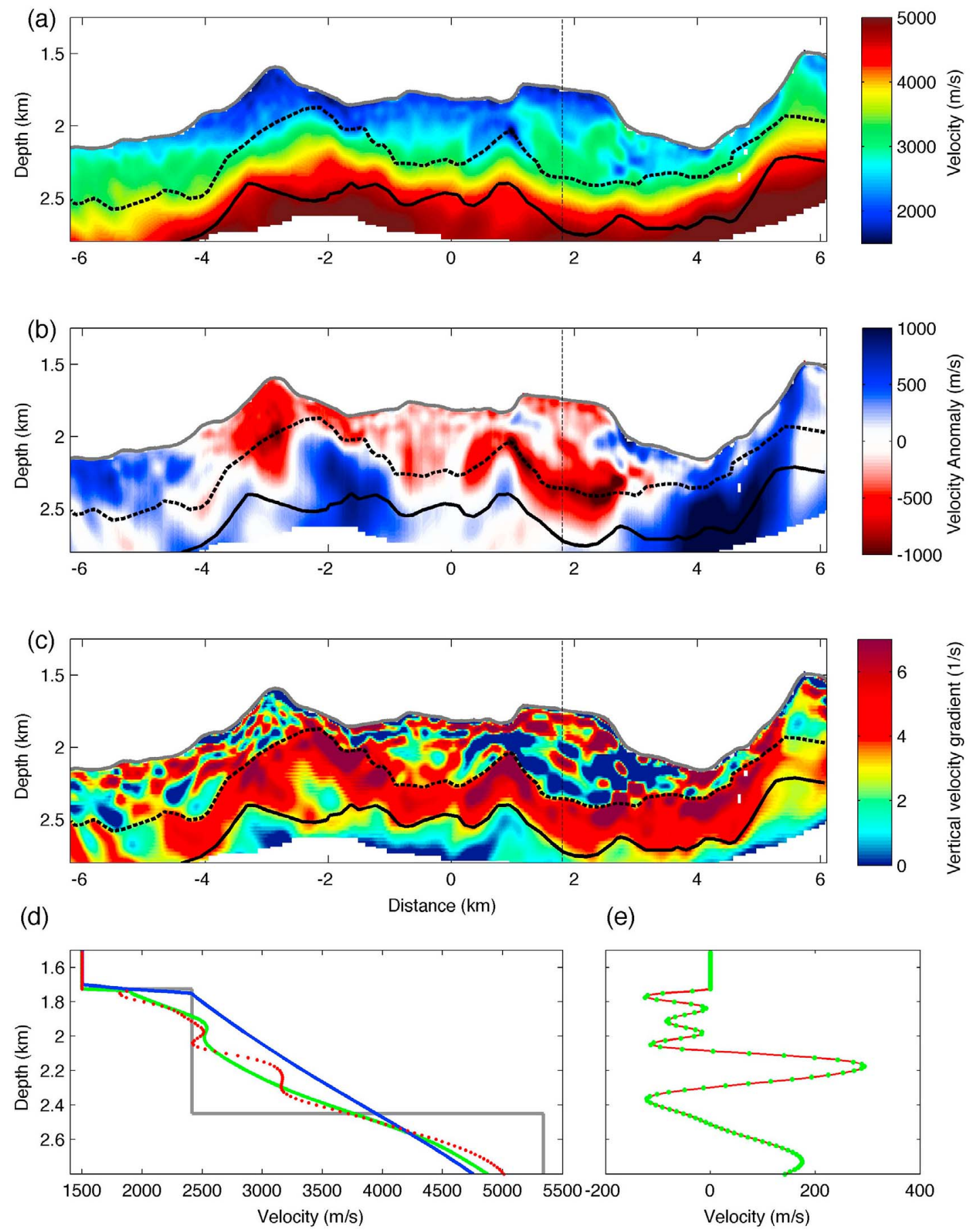

Figure 3. Upper crustal velocity structure of the Lucky Strike volcano beneath the seismic line 39. (a) Velocity section. (b) Velocity anomaly section created by subtracting the average 1D velocity profile from the 3D SOBE tomography survey, within -6 and $-4 \mathrm{~km}$ in the median valley [Arnulf et al., 2011]. (c) Vertical velocity gradient. The thin vertical dashed black line shows the location of the vertical velocity profiles presented in Figures $3 \mathrm{~d}$ and $3 \mathrm{e}$. The thick black line and the thick dashed lines mark, respectively, the bottom and the top of the layer 2A high velocity gradient zone. (d) Representative 1-D velocity models of the Lucky Strike volcano from OBS tomography (blue line [Seher et al., 2010b]), from SOBE tomography (green line [Arnulf et al., 2011]) and from waveform inversion (red dots, this study). The grey line corresponds to the interval velocity model related to the typical RMS velocity model used to stack events within the layer $2 \mathrm{~A}\left(\mathrm{v}_{\mathrm{RMS}}=1500 \mathrm{~m} / \mathrm{s}\right.$ in the water layer, $\mathrm{v}_{\mathrm{RMS}}=2200 \mathrm{~m} / \mathrm{s}$ in the layer $2 \mathrm{~A}, \mathrm{v}_{\mathrm{RMS}}=3000 \mathrm{~m} / \mathrm{s}$ just above the AMC reflector [Singh et al., 2006]). (e) Velocity differences between the SOBE tomography and the waveform inverted velocity models. 


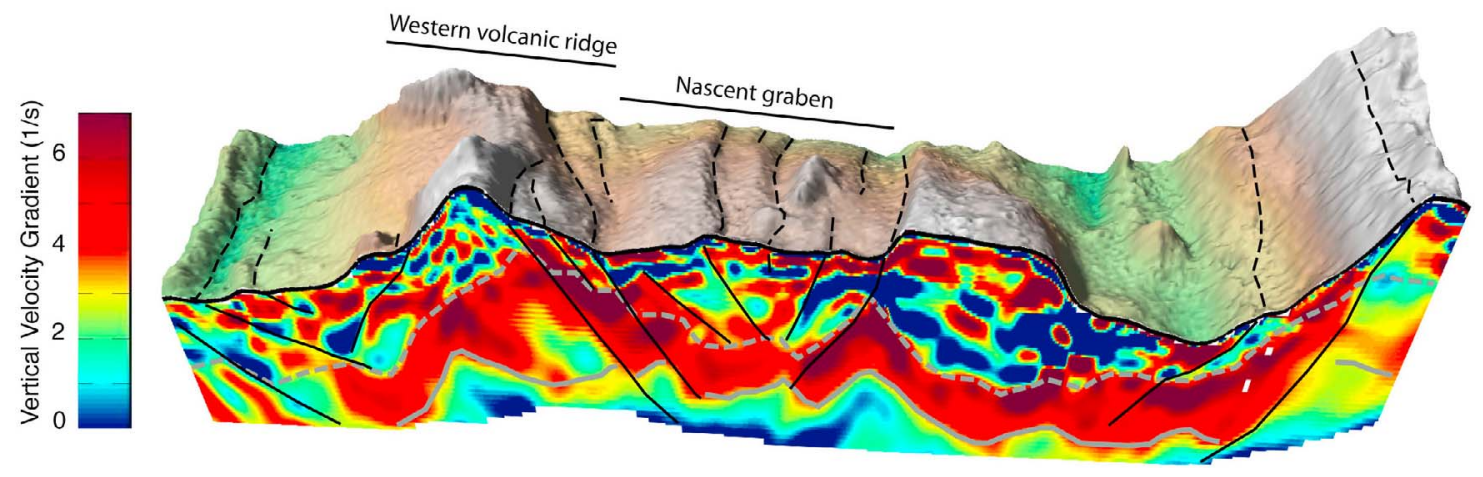

Figure 4. Three-dimensional schematic view of the shallow crust. The background represents the vertical P-wave velocity gradient of the best-fit FWI model. Grey line and dashed grey line represent respectively the bottom and the top of the layer 2A high velocity gradient zone. The black lines and the dashed black lines mark the main regional faults within the velocity model and on the bathymetry respectively.

signal because of phase errors, were reduced to $31.6 \%$ by the final iteration. Furthermore, the correlation coefficient between the observed data and synthetics, another objective measure of fit increased from 0.29 to a final value of 0.81 .

\section{Results and Discussion}

[9] The P-wave velocity structure beneath the seismic line 39, north of the Lucky Strike volcano is presented in Figures 3 and 4. Several 50-150 m thick layered features are observed within the shallow crust above the main layer $2 \mathrm{~A}$ high velocity gradient zone, and might correspond to discrete steps in the average porosity. Geological mapping and rock sampling observations carried out at Lucky Strike site [Fouquet et al., 1994; Ondréas et al., 1997, 2009; Humphris et al., 2002], record a wide diversity of volcanic deposits - massive flows, pillow lavas, draped lavas, and lobate lavas and even volcanic breccias, resulting from explosive dynamics, but these are, in general too thin to account for the observed layers. However, the increase in upper layer $2 \mathrm{~A}$ velocity with age is sufficiently rapid that these layers may correspond to different eruption sequences that are separated by a period of quiescence. The velocity anomaly section (Figure 3b), computed by subtracting the average $1 \mathrm{D}$ velocity profile from the 3D SOBE tomography model [Arnulf et al., 2011], further shows that the upper layer of highly variable velocity gradient is thicker beneath the central volcano and if this layer represents stacked lava sequences, it suggests that the central volcano is a constructional feature emplaced within the axial valley. Furthermore, Figures 3 and 4 and Figures S1, S2, and $\mathrm{S} 3$ in the auxiliary material show that the faults mapped on the seafloor are identified at depths as they shift and rotate different lava sequences on the vertical velocity gradient section, notably in the vicinity of the two main faults that bound the nascent rift valley at $-1.6 \mathrm{~km}$ and $1 \mathrm{~km}$ across axis. ${ }^{1}$ Moreover, these faults are located in the vicinity of some recent volcanic edifices, suggesting the continuing interplay of magmatic and tectonic processes near segment center. A synthetic test was further performed to assess that the fine-scale structures present in the shallow crust beneath the LuckyStrike volcano are required by the data and are not an inversion artifact (Figures S4 and S5 in the auxiliary material).

${ }^{1}$ Auxiliary materials are available in the HTML. doi:10.1029/ 2012GL051064.
[10] In addition, Figures $3 \mathrm{~d}$ and $3 \mathrm{e}$ show that compared to the OBS tomography model [Seher et al., 2010b], the SOBE tomography model [Arnulf et al., 2011] improves velocities in the upper $\sim 700 \mathrm{~m}$ of the crust and the waveform inversion improves the gradient information. A comparison with the interval velocity model related to the typical root mean square (RMS) velocity model used to stack events within the layer $2 \mathrm{~A}$ $\left(\mathrm{v}_{\mathrm{RMS}}=1500 \mathrm{~m} / \mathrm{s}\right.$ in the water layer, $\mathrm{v}_{\mathrm{RMS}}=2200 \mathrm{~m} / \mathrm{s}$ in the layer $2 \mathrm{~A}, \mathrm{~V}_{\mathrm{RMS}}=3000 \mathrm{~m} / \mathrm{s}$ just above the $\mathrm{AMC}$ reflector) [Singh et al., 2006] is also shown. One can see that the structural/layered model from stacking of seismic reflection data and smooth velocity model from OBS tomography both give conflicting but incomplete images of the upper crust; One overemphasizes the structure whereas the other smooths it. The strength of FWI is that it unifies the structural and velocity information into a single consistent model.

[11] Finally compared with a previous frequency-domain acoustic waveform tomography experiment carried out over the Kane oceanic core complex on the Mid-Atlantic Ridge by Canales [2010], our methodology based on a combination of SOBE method and elastic waveform inversion has achieved a significantly higher misfit reduction, 76\% compared to $2-9 \%$ in the work by Canales [2010]. Differences in misfit reduction could reflect both the adequacy of the initial model, the effectiveness of the waveform tomography as well as differences in the tectonic setting. However, there are identifiable elements of our waveform inversion flow that help explain the larger misfit reduction. The downward continuation filters much of the background noise that can't be modelled, and the use of time domain computations permits tighter windowing of arrivals. The improved signal to noise ratio permits much large misfit reduction and possibly also enhances the convergence of the waveform inversion. An auxiliary advantage of the time domain is that we can look directly at residuals, leading to a more confidence in the inverted model.

\section{Conclusion}

[12] In this study we have shown that elastic full waveform inversion when used in combination with downward continuation is a powerful tool for determining the fine-scale seismic structure of the oceanic crust. This combination sidesteps the problem of the high amplitude seafloor scattering effects that degrades common post-stack seismic images and does not allow a fine-scale imagery of the oceanic crust. The 
young shallow crust beneath the Lucky Strike volcano is interpreted as piled up volcanic sequences emplaced within the axial valley. These volcanic units are shifted and rotated by several normal faults that are strongly correlated with seafloor observations. Our results have thus demonstrated the advantage of using a waveform inversion technique to unify the wide-angle reflection/refraction energy and the true refraction arrivals into a single high-resolution, selfconsistent image, which could help to better understand the links between magmatic, tectonic and hydrothermal processes at ocean spreading centers.

[13] Acknowledgments. We thank the captain, crew and scientific party from GENAVIR of cruise SISMOMAR of the RV/l'Atalante for their assistance. This study also benefited from reviews by Tim Minshull and an anonymous reviewer. The INSU MOMAR program funded the acquisition of SISMOMAR project. This is an Institut de Physique du Globe de Paris contribution 3284. This research was also supported by grant OCE0826481 from the U.S. National Science Foundation.

[14] The Editor thanks Timothy Minshull and an anonymous reviewer for assisting with the evaluation of this paper.

\section{References}

Arnulf, A. F., S. C. Singh, A. J. Harding, G. M. Kent, and W. Crawford (2011), Strong seismic heterogeneity in layer $2 \mathrm{~A}$ near hydrothermal vents at the Mid-Atlantic Ridge, Geophys. Res. Lett., 38, L13320, doi:10.1029/ 2011 GL047753.

Berryhill, J. R. (1979), Wave-equation datuming, Geophysics, 44, 1329 1344, doi:10.1190/1.1441010.

Berryhill, J. R. (1984), Wave-equation datuming before stack, Geophysics, 49, 2064-2066, doi:10.1190/1.1441620.

Canales, J. P. (2010), Small-scale structure of the Kane oceanic core complex, Mid-Atlantic Ridge $23^{\circ} 30^{\prime} \mathrm{N}$, from waveform tomography of multichannel seismic data, Geophys. Res. Lett., 37, L21305, doi:10.1029/2010GL044412.

Canales, J. P., R. S. Detrick, S. M. Carbotte, G. M. Kent, J. B. Diebold, A. J. Harding, J. Babcock, M. R. Nedimovíc, and E. van Ark (2005), Upper crustal structure and axial topography at intermediate spreading ridges: Seismic constraints from the Juan de Fuca Ridge, J. Geophys. Res., 110, B12104, doi:10.1029/2005JB003630.

Christeson, G., G. Kent, G. Purdy, and R. Detrick (1996), Extrusive thickness variability at the East Pacific Rise, $9^{\circ}-10^{\circ} \mathrm{N}$ : Constraints from seismic techniques, J. Geophys. Res., 101(B2), 2859-2873, doi:10.1029/95JB03212.

Christeson, G. L., K. D. McIntosh, and J. A. Karson (2007), Inconsistent correlation of seismic layer $2 \mathrm{a}$ and lava layer thickness in oceanic crust, Nature, 445, 418-421, doi:10.1038/nature05517.

Collier, J. S., and S. S. Singh (1997), Detailed structure of the top of the melt body beneath the East Pacific Rise at $9^{\circ} 40^{\prime} \mathrm{N}$ from waveform inversion of seismic reflection data, J. Geophys. Res., 102(B9), 20,287-20,304, doi:10.1029/97JB01514.

Combier, V. (2007), Mid-ocean ridge processes. Insights from 3D reflection seismics at $9^{\circ} \mathrm{N}$ OSC on the East Pacific Rise, and the Lucky Strike Volcano on the Mid-Atlantic Ridges, PhD thesis, Lab. de Geosci. Mar., Inst. de Phys. du Globe de Paris, Paris.

Detrick, R. S., H. D. Needham, and V. Renard (1995), Gravity anomalies and crustal thickness variations along the Mid-Atlantic Ridge between $33^{\circ} \mathrm{N}$ and $40^{\circ} \mathrm{N}, J$. Geophys. Res., 100, 3767-3787, doi:10.1029/94JB02649.

Fouquet, Y., J.-L. Charlou, I. Costa, J.-P. Donval, J. Radford-Knoery, H. Pellé, H. Ondréas, N. Lourenço, M. Ségonzac, and M. Kingston Tivey (1994), A detailed study of the Lucky Strike hydrothermal site and discovery of a new hydrothermal site: Menez Gwen: Preliminary results of the DIVA1 cruise (5-29 May, 1994), InterRidge News, 3(2), 14-17.

Gardner, G. H. F., L. W. Gardner, and A. R. Gregory (1974), Formation velocity and density-The diagnostic basics for stratigraphic traps, Geophysics, 39, 770, doi:10.1190/1.1440465.

Hamilton, E. L. (1978), Sound velocity-density relations in sea-floor sediments and rocks, J. Acoust. Soc. Am., 63, 366-377, doi:10.1121/1.381747.

Harding, A., J. Orcutt, M. Kappus, E. Vera, J. Mutter, R. Buhl, R. Detrick, and T. Brocher (1989), Structure of young oceanic crust at $13^{\circ} \mathrm{N}$ on the East Pacific Rise from expanding spread profile, J. Geophys. Res., 94(B9), 12,163-12,196, doi:10.1029/JB094iB09p12163.

Harding, A. J., G. M. Kent, and J. A. Orcutt (1993), A multichannel seismic investigation of the upper crustal structure at $9^{\circ} \mathrm{N}$ on the East Pacific Rise: Implications for crustal accretion, J. Geophys. Res., 98, 13,925-13,944, doi:10.1029/93JB00886.

Humphris, S. E., D. J. Fornari, D. S. Scheirer, C. R. German, and L. M. Parson (2002), Geotectonic setting of hydrothermal activity on the summit of Lucky Strike Seamount ( $37^{\circ} 17^{\prime} \mathrm{N}$, Mid-Atlantic Ridge), Geochem. Geophys. Geosyst., 3(8), 1049, doi:10.1029/2001GC000284.

Hussenoeder, S. A., G. M. Kent, and R. S. Detrick (2002), Upper crustal seismic structure of the slow spreading Mid-Atlantic Ridge, $35^{\circ} \mathrm{N}$ : Constraints on volcanic emplacement processes, J. Geophys. Res., 107(B8), 2156, doi:10.1029/2001JB001691.

Kent, G. M., A. J. Harding, and J. A. Orcutt (1993), Distribution of magma beneath the East Pacific Rise between the Clipperton transform and the $9^{\circ} 17^{\prime} \mathrm{N}$ deval from forward modeling of common depth point data, J. Geophys. Res., 98, 13,945-13,969, doi:10.1029/93JB00705.

Larkin, S. P., and A. Levander (1996), Wave equation datuming for improving deep crustal seismic images, Tectonophysics, 264, 371-379, doi:10.1016/S0040-1951(96)00137-0.

Levander, A. R. (1988), Fourth-order finite-difference P-SV seismograms, Geophysics, 53, 1425-1436, doi:10.1190/1.1442422.

Moreira, M., R. Doucelance, M. D. Kurz, B. Dupré, and C. J. Allegre (1999), Helium and lead isotope geochemistry of the Azores Archipelago, Earth Planet. Sci. Lett., 169, 189-205, doi:10.1016/S0012-821X(99)00071-0.

Ondréas, H., Y. Fouquet, M. Voisset, and J. Radford-Knoery (1997), Detailed study of three contiguous segments of the Mid-Atlantic Ridge, south of the Azores $\left(37^{\circ} \mathrm{N}\right.$ to $\left.38^{\circ} 30^{\prime} \mathrm{N}\right)$, using acoustic imaging coupled with submersible observations, Mar. Geophys. Res., 19, 231-255, doi:10.1023/A:1004230708943.

Ondréas, H., M. Cannat, Y. Fouquet, A. Normand, P. M. Sarradin, and J. Sarrazin (2009), Recent volcanic events and the distribution of hydrothermal venting at the Lucky Strike hydrothermal field, Mid-Atlantic Ridge, Geochem. Geophys. Geosyst., 10, Q02006, doi:10.1029/ 2008 GC002171.

Operto, S., C. Ravaut, L. Improta, J. Virieux, A. Herrero, and P. Dell'Aversana (2004), Quantitative imaging of complex structures from dense wideaperture seismic data by multiscale traveltime and waveform inversions: A case study, Geophys. Prospect., 52(6), 625-651, doi:10.1111/j.13652478.2004.00452.x.

Pratt, R. G. (1999), Seismic waveform inversion in the frequency domain. Part I: Theory and verification in a physical scale model, Geophysics, 64, 888-901, doi:10.1190/1.1444597.

Sears, T. J., P. J. Barton, and S. C. Singh (2010), Elastic full waveform inversion of multicomponent ocean-bottom cable seismic data: Application to Alba Field, U. K. North Sea, Geophysics, 75(6), R109, doi: $10.1190 / 1.3484097$

Seher, T., W. C. Crawford, S. C. Singh, and M. Cannat (2010a), Seismic layer $2 \mathrm{~A}$ variations in the Lucky Strike segment at the Mid-Atlantic Ridge from seismic reflection measurements, J. Geophys. Res., 115, B07107, doi:10.1029/2009JB006783.

Seher, T., W. C. Crawford, S. C. Singh, M. Cannat, V. Combier, and D. Dusunur (2010b), Crustal velocity structure of the Lucky Strike segment of the Mid-Atlantic Ridge at $37^{\circ} \mathrm{N}$ from seismic refraction measurements, J. Geophys. Res., 115, B03103, doi:10.1029/2009JB006650.

Seher, T., S. C. Singh, W. Crawford, and J. Escartin (2010c), Upper crustal velocity structure beneath the central Lucky Strike Segment from seismic refraction measurements, Geochem. Geophys. Geosyst., 11, Q05001, doi:10.1029/2009GC002894.

Shipp, R. M., and S. C. Singh (2002), Two-dimensional full wavefield inversion of wide-aperture marine seismic streamer data, Geophys. J. Int., 151(2), 325-344, doi:10.1046/j.1365-246X.2002.01645.x.

Shtivelman, V., and A. Canning (1988), Datum correction by waveequation extrapolation, Geophysics, 53(10), 1311-1322, doi:10.1190/ 1.1442409 .

Singh, S. C., et al. (2006), Discovery of a magma chamber and faults beneath a Mid-Atlantic Ridge hydrothermal field, Nature, 442, 1029-1032, doi:10.1038/nature05105.

Sirgue, L., and R. G. Pratt (2004), Efficient waveform inversion and imaging: A strategy for selecting temporal frequencies, Geophysics, 69, 231-248, doi:10.1190/1.1649391.

Tarantola, A. (1986), A strategy for nonlinear elastic inversion of seismic reflection data, Geophysics, 51, 1893-1903, doi:10.1190/1.1442046.

Virieux, J., and S. Operto (2009), An overview of full-waveform inversion in exploration geophysics, Geophysics, 74(6), WCC1, doi:10.1190/ 1.3238367 .

A. F. Arnulf and A. J. Harding, Cecil H. and Ida M. Green Institute of Geophysics and Planetary Physics, Scripps Institution of Oceanography, University of California, San Diego, 9500 Gilman Dr., La Jolla, CA 92093, USA.

W. Crawford and S. C. Singh, Laboratoire de Géosciences Marines, Institut de Physique du Globe de Paris, Boîte 89, 4 place Jussieu, F-75252 Paris CEDEX 05, France.

G. M. Kent, Nevada Seismological Laboratory, University of Nevada, Reno, MS-174, Reno, NV 89557, USA. 